\title{
PARTAI POLITIK SEBAGAI BADAN HUKUM DALAM SISTEM KEPARTAIAN DI INDONESIA
}

\author{
Mohammad Mahmudi \\ Program Magister Ilmu Hukum \\ Pascasarjana Universitas Islam Malang \\ Email : mahmudi1957@gmail.com
}

\begin{abstract}
Abstrak
Partai-partai politik di Indonesia tumbuh dan berkembang pesat, oleh karena itu, perlu ada ide baru dalam upaya mengembangkan dan membubarkan partai politik yang bangkrut untuk menciptakan sistem perpisahan Indonesia adalah sistem multipartai yang sederhana. Hasil dari penelitian ini menunjukkan bahwa pembentukan partai politik yang signifikan dan upaya untuk menyederhanakan partai politik dengan melalui tahap yang tidak biasa adalah melalui aplikasi partai politik kebangkrutan ke Mahkamah Konstitusi yang tujuannya adalah untuk efisiensi negara - anggaran yang dikeluarkan untuk partai politik serta menjadikan sistem perpisahan Indonesia sebagai sistem multi-partai yang sederhana namun dalam artian melakukan gagasan untuk memperhatikan beberapa faktor penting termasuk: prinsip demokrasi, rasional, dan non-diskriminatif.
\end{abstract}

Kata kunci: Partai politik, pembubaran partai politik, sistem Multi Partai yang sederhana.

\begin{abstract}
Political parties in Indonesia are growing and growing rapidly, therefore, there needs to be a new idea in the effort to develop and dissolve the bankrupt political party in order to create a system Indonesian parting is a simple multiparty system. The results of this study show that the establishment of a significant political party and efforts to simplify the political party by going through an unusual stage is by means of The application of the bankruptcy political party to the Constitutional Court of its purpose is to efficiencies the country-issued budget for political parties as well as making the system of Indonesia's parting systems a multi-party system that is simple but in terms Do the idea of having to pay attention to several important factors including: democratic, rational, and Non-discriminatory principles.
\end{abstract}

Keywords: Political parties, political party disbandment, simple Multi Party system.

\section{PENDAHULUAN}

Partai politik merupakan cermin kemerdekaan berserikat (freedom of asssociation) dan berkumpul (freedom assembly) sebagai perwujudan dari kemerdekaan berfikir dan berpendapat (freedom of tought) serta kebebasan 
berekspresi (freedom of expression). Oleh karena itu, kemerdekaan berserikat sangat dilindungi oleh setiap undang - undang dasar negara demokrasi konstitusional ( constitutional democracy) atau negara hukum demokratis (democratsche rechtstaat). ${ }^{1}$

Pertumbuhan atau perkembangan partai politik di Indonesia sangatlah pesat di tandai dari banyaknya partai politik yang baru terbentuk, partai politik di Indonesia merupakan bagian dari kehidupan perpoltikan di Indonesia selama kurun waktu seratus tahun terakhir. Partai politik juga digunakan dalam upaya memperjuangkan bangsa Indonesia di jaman pendudukan colonial belanda sampai pada saat pendudukan jepang. Namun dalam upaya tersebut partai justru mengalami kesukaran untuk membentuk kesatuan atau front dalam upaya berjuang untuk kemerdekaan Indonesia baik pada zaman koloneal belanda atau jepang.

Maklumat Pemerintah Nomor X Pada 3 November 1945 tetntang anjuran Pemerintah tentang Pembentukan - Pembentukan Partai Politik, adalah dasar dan awal dari terciptanya sistem multi partai di negara republik Indonesia. sistem multi partai merupakan salah satu sistem kepartaian dalam sistem demokrasi negara hukum (democratische rechstaat). Namun sistem multi partai menyebabkan ketidak stabilan dalam berjalannya proses pemerintahan dibuktikan dengan badan konstituante yang tidak dapat menyelasikan tugasnya dalam upaya membuat dan merumuskan konstitusi hingga pada tahun 1959. Penyebabnya adalah terjadinya perbedaan mendasar antara dasar negara islam dan pancasila yang tidak menemukan titik temu. Sampai pada saat pemberlakuan kembali Undang - Undang Dasar Negara Republik Indonesia tidak menemukan kesimpulan yang tepat antara tidak adanya perubahan atau dengan adanya perubahan.

Berdasarkan hal tersebut maka presiden Republik Indonesia Ir. Soekarno kemudian mengluarkan Dekrit Presiden yang berisi tentang pemberlakuan kembali Undang _ Undang Dasar 1945 menjadi Konstitusi Negara Republik Indonesia.

Pada masa demokrasi terpimpin, ketidak stabilan yang di timbulkan akibat banyaknya partai politik ini kemudian menimbulkan sebuah prinsip pembatasan partai politik yaitu presiden mengeluarkan Petetapan Presiden No. 7 Tahun 1959 pada tanggal 31 Desember Tahun 1959 Tentang syarat - syarat dan penyederhanaan partai. Konsep sistem kepartaian di Indonesia kemudian terjadi pembatasan lagi ketika pada resim orde barunya Soeharto dengan cara yang lebih radikal yaitu di muka sepuluh partai termasuk golkar, Presiden Soeharto mengumumkan sarannya agar partai mengelompokkan diri untuk mempermudah kampanye pemilihan umum tanpa partai kehilangan identitasnya masing - masing atau di bubarkan sama sekali. ${ }^{2}$

Setelah kemudian runtuhnya rezim Soeharto pada tahun 1998 maka juga memberi pengaruh kepada sistem kepartaian yang terjadi di Indonesia, pada saat era reformasi runtuhnya rezim juga berakibat kepada runtuhnya pembatasan partai politik yaitu dengan berdirinya jumlah partai- politik yang cukup banyak.

${ }^{1}$ Jimly Asshiddiqie, Pengantar Ilmu Hukum Tata Negara Jilid I. Sekretariat Jendral dan kepaniteraan Mahkamah Konstitusi RI, Jakarta 2006. Hal 338.

${ }^{2}$ Meriam Budiarjdo., Op Cit. 2010 hal 445 
Upaya pembatasan partai politik terus berlangsung siring dengan perubahan Undang - undang tentang partai politik, yakni Undang - Undang Nomor 2 Tahun 2008 Tentang Partai Politik. Tujuan partai politik secara umum di atur dalam ketentuan pasal10 huru a dan pasal 10 huruf d Undang - Undang No. 2 Tahun 2008 tentang partai politik adalah:

a. Mewujudkan cita - cita nasional bangsa Indonesia sebagaimana dimaksud dalam pembukaan Undang - Undang Dasar Negara Republik Indonesia;

b. Mewujudkan kesejahteraan bagi seluruh rakyat Indonesia.

Ketentuan pasal 10 huruf a dan d Undang - Undang No.2 Tahun 2008 tersebut merupakan suatu nilai yang terkandung didalam partai politik adalah dengan Semata - mata hanya untuk mensejahterakan rakyat. Namun pada konteks politik praktis partai politik adalah dianggap sebagai sumber dimana penyalahgunaan wewenang terjadi, dengan itu maka upaya pembatasan pertumbuhan partai politik perlu adanya suatu pembatasan.

Dalam suatu fungsi partai politik secara umum adalah mencari dan mempertahankan kekuasaan di dalam sistem ketata pemerintahan untuk mewujudkan program - program yang disusun berdasarkan ideologi partai politik itu sendiri. adapun caranya dalam mencari dan mempertahankan kekuasaan suatu partai politik didalam suatu sistem pemerintahan adalah mengikuti pemilihan umum.

Selain sesudah partai politik di nyatakan lulu verifikasi oleh kementrian hukum dan hak asasi manusia yang selanjutnya disebut dengan (Kemenkumham) harus medaftarkan partai politik baru tersebut sebagai suatu badan hukum sehingga partai politik sebagai organisasi yang berbadan hukum. Partai politik sebgai sebuah organisasi, adalah sama denganorganisasi yang lain yaitu di bentuk atas dasar kebebsan berserikat, dan eksistensinya dalam lalu lintas hukum di ketahui jika partai politik berbadan hukum.

menurut han kelsen, beberapa orang dikatakan membentuk suatu organisasi yang berbadan hukum atau korporasi, jika tindakanya di atur oleh suatu atanan yaitu sistem norma, partai politik sebgai bdan hukum juga memliki konstitusi yang berisi aturan - aturan penting bagi partai politik tersebut. ${ }^{3}$

Berdasarakan Pasal 3 Undang - undang No. 2 Tahun 2011 Tentang partai politik adalah bahwa partai politik harus di daftarkan kepada kementrian menjadi badan hukum. Berkaitan dengan hal tersebut partai politik harus menjadi badan hukum maka akan mendapatkan multi tafsir yang berbeda di antara ahli hukum yaitu terkait dengan status partai politik sebagai badan hukum.

Dalam ilmu hukum aadalah di jelaskan bahwa subjek hukum (legal subject) adalah setiap penyandang Hak dan Kewajiban lalu lintas atau hubunganhubungan hukum. Pembawa hak dan kewajiban itu dapat merupakan orang yang bias disebut dengan Naturlijke Person (menselijk person) atau bukan orang yang biasa disebut pula dengan Rechtpersoon. Rechtpersoon itulah yang biasa dikenal sebagai badan hukumyang merupakan persona cta atau orang yang diciptakan oleh hukum sebgai persona (orang diktif). ${ }^{4}$

${ }^{3}$ Moh. Ali Safa'at : Pembubaran Partai Politik Hal 19-20

4 Jimly Asshiddiqie, Perkembangan \&konsolidasi Lembaga negara, Jakarta Sinar Grafika, 2006, Hal 60 
Didalam badan hukum juga ada persyaratan tentang tujuan yang tidak bertentangan dengan peraturan perundang - undangan .tujuan dari badan hukum dapat berupa tujuan yang bersifat ideal tertentu, ataupun tujuan yang relatif lebih praktis dan bersifat komersial atau yang berkaitan dengan keuntungan. Misalnya, badan hukum dapat berorentasi mencari keuuntungan (pro t-oriented) atau tidak mencari keuntungan (Non-pro oriented). Tujuan - tujuan itulah harus merupakan tujuan badan hukum sebagai institusi yang terpisah dari tujuan - tujuan yang bersifat pribadi dari para pendirinya ataupun pengurusnya. Karena itu tujuan tujuan istitusi badan hukum sangatpenting dirumuskan secara jelas sehingga upaya - upaya yang perlu dilakukan untuk mencapainya juga menjadi jelas. ${ }^{5}$

Kejelasan suatu hubungan usaha adalah tujuan untuk menentukan kompetensi dan kewenangan badan hukum sebgai suatu subjek hukum dalam lalu lintas hukum. Kejelasan ini adalah sangat penting karena badan hukum hanya dapat bertindak melalui perantara organ jabatan yang ada didalam suatu badan hukum, yang nantinya pemegang jabaytan itu adalah orang per orangan, pengurusnya atau anggotanya. Dai ini akan jelas mana yang bertindak sebgai pribadi dan yang bertindak sebagai badan hukum (rechpersoon).

Didalam partai poltitik sebagai badan hukum juga dapat di pailitkan ketika mengalami kegagalan dalam proses berjalanya suatu partai politik, partai politik adalah sebagai badan hukum yang secara sah di bentuk dan di daftarkan melalui kementrian dan ketika mengalami suatu kegagalan dalam fungsinaris atau tindakannya sebagai badan hukum maka partai politik dapat juga di lakukan proses pemailitan sebagaimana badan hukum yang lainnya.

Dengan demikian, ketika partai politik dapat di pailitkan bukan tidak mungkin bahwa hal ini dapat menjadi solusi terhadap upaya penyederhanaan partai politik dengan melihat banyaknya partai politik di Indonesia yang tumbuh dengan pesatnya dan hanya akan menambah beban anggaran pendapatan belanja negara sebagaimana bahwa anggaran partai politik di ambilkan dari anggaran pendapatan negara, maka solusinya adalah pemailitan partai politik.

\title{
METODE PENELITIAN
}

Jenis pendekatan yang dilakukan pada penelitian ini adalah pendekatan undang - undang (statute approach) yang dilakukan dengan menelaah semua Undang-Undang dan regulasi yang bersangkut paut dengan isu hukum yang sedang di tangani, pendekatan akan membuka cakrawala peneliti dalam mempelajari konsistensi kesesuaian antara undang - undang yang satu dengan yang lainnya atau undang - undang dengan undang - undang dasar atau regulasi dengan undang - undang. ${ }^{6}$

Selanjutnya adalah menggunakan Pendekatan conceptual opproach, yang dilakukan dengan menelaah pandangan-pandangan dan doktrin-doktrin dalam ilmu hukum dan perkembangan peraturan mengenai isu yang dihadapi. ${ }^{7}$

\subsubsection{Bahan hukum}

\author{
${ }^{5}$ Ibid, Hal 64. \\ 6 Peter Mahmud Marzuky, Penelitian Hukum. Cetakan Keenam, (Jakarta; Kencana
} ,2010), hal .29.

${ }^{7}$ Ibid, hal. 137 
Dalam proses pengumpulan bahan hukum peneliti menggunakan jenis sumber hukum primer, sekunder, dan tersier, yaitu:

a. Sumber hukum primer didalam hal ini adalah Undang - Undang Dasar Negara Republik Indonesia 1945, Undang - undang No.2 Tahun 2008, Undang - undang No 2 Tahun 2011, Undang - undang No 2 tahun 1999, Undang - undang No 37 Tahun 2004 dan juga peraturan perundang undangan terkait dengan focus penulisan di dalam tesis ini.

b. Sumber hukum sekunder merupakan bahan hukum yang diperoleh dari referensi buku-buku hukum dan termasuk tesis, sikripsi, desertasi hukum dan jurnal hukum. ${ }^{8}$ Sumber hukum sekunder adalah memberikan penjelasan dan tafsiran terhadap sumber bahan hukum primer seperti buku ilmu hukum, jurnal hukum, laporan hukum, media cetak atau eletronik, pendapat para sarjana, kasus - kasus hukum seta simposium yang dilakukan pakar terkait dengan pembahasan ${ }^{9}$ tentang partai politik sebgai badan hukum dalam sistem kepartaian di Indonesia.

c. Bahan hukum tersier yakni bahan hukum yang memberikan petunjuk maupun penjelassan terhadap bahan hukum primer dan skunder;contohnya kamus, Ensiklopedia, Indeks komulatif, dan seterusnya (fakultatif). ${ }^{10}$ Adapun bahan hukum tersier yang digunakan dalam penulisan Tesis ini adalah meliputi berbagai media seperti media cetak, media elektronik, kamus hukum dan internet.

\subsubsection{Teknik pengumpulan bahan hukum}

pengumpulan bahan hukum dimaksudkan untuk memperoleh bahan hukum dalam penelitian. Teknik pengumpulan bahan hukum yang mendukung dan berkaitan dengan pemaparan penelitian ini adalah studi dokumen (studi kepustakaan). Studi dokumen adalah suatu alat pengumpulan bahan hukum yang dilakukan melalui bahan hukum tertulis dengan mempergunakan content analisys. ${ }^{11}$ Teknik ini berfungsi guna mendapatkan landasan - landasan teori dengan mengkaji buku - buku, peraturan perundang - undangan, jurnal, dan hasil - hasil penelitian - penelitian lainnya baik cetak maupun dalam bentuk eletronik yang langsung berhubungan dengan partai politik sebagai badan hukum dalam sistem kepartaian di Indonesia.

\subsubsection{Teknik Analisis Data}

4. Penggunaan metode deduksi berpangkal dari pengajuan premis mayor (pernyataan yang bersifat umum). Kemudian diajukan premis minor (bersifat khusus), dari kedua premis itu kemudian ditarik suatu kesimpulan atau

\section{${ }^{8}$ Peter Mahmud Marzuky. Op.Cit.hal 155}

${ }^{9}$ Jhonny Ibrahim, Teori Dan Metodologi Penelitian Hukum Normatif, Bayumedia, Malang, 2006, hal.392.

${ }^{10}$ Maria SW.Sumardjono, Metodologi Penelitian Ilmu Hukum, (Yogyakarta, Universitas Gajah Mada, 2014), hal.17.

\footnotetext{
${ }^{11}$ Peter Mahmud Marzuky. Op.Cit., hal. 21
} 
conclusion. Akan tetapi di dalam argumentasi hukum, silogisme hukum tidak sesederhana silogisme tradisional. ${ }^{12}$ Penelitian ini menggunakan teknik analisis data dengan logika deduktif, adapun yang dimaksudkan dengan logika deduktif atau pengolahan bahan hukum dengan cara deduktif yaitu menjelaskan suatu hal yang bersifat umum kemudian menariknya menjadi kesimpulan yang lebih khusus.

\section{PEMBAHASAN}

Kebijakan penyederhanaan Partai politik sudah berlaku semenjak zaman awal kemerdekaan, upaya mengkontruksikan prinsip-prinsip hukum penyederhanaan partai politik harus dimulai dari landasan filosofis bangsa Indonesia sendiri yakni Pancasila sebagai cita-cita hukum nasional Indonesia. kebijakan partai politik dapat dilihat dari persyaratan kuantitatif dan kualitatif dan pendaftaran partai politik sebagai badan hukum.

4.2.1. Undang-Undang Nomor 2 Tahun 1999

Undang-undang Nomor 2 Tahun 1999 merupakan produk hukum setelah runtuhnya rezimorde baru yang berkuasa selama 32 tahun undang-undang ini menggantikan Undang-undang Nomor 3 Tahun 1975 Tentang Partai Politik dan golongan Karya dan Undang-Undang Nomor 3 Tahun 1985 Tentang Perubahan Undang-Undang Nomor 3 Tahun 1975 yang di pandang tidak dapat menampung aspirasi politik yang sedang berkembang.

Didalam undang-undang Nomor 2 Tahun 1999 terdapat persyaratanpersyaratan yang membatasi partai politik, berdasarkan Undang-Undang Nomor 2 Tahun 1999 dalam hal membentuk partai politik harus dibentuk oleh minimal 50 orang warga negara Indonesia yang telah berusia sekurang0kurangnya 21 tahun yang dijelaskan dalam pasal 2 ayat 1 :

Sekurang-kurangnya 50 (lima puluh) orang warga negara Republik Indonesia yang telah berusia 21 (dua puluh satu) tahun dapat membentuk Partai Politik.

Syarat pembentukan partai politik kemudian diatur dalam pasal 2 ayat (2) yang terdapat syarat asas/ideology pembentukan partai dengan mencantumkan pancasila dalam anggran dasar Partai, Asas atau Ciri, Aspirasi dan program partai tidak bertentangan dengan landasan falsafah negara yaitu pancasila, tidak menggunakan nama atau lambing yang sama dengan lambing negra asing, bendera Negara Republik Indonesia, bendera negara asing, gambar perorangan serta lambang partai lain yang dijeaskan dalam pasal 2 ayat (2):

Partai Politik yang dibentuk sebagaimana ddimaksud ayat (1) harus memenuhi syarat:

a. Mencamtumkan Pancasila sebagai dasar negara dari Negara Kesatuan Republik Indonesia dalam anggaran dasar partai:

b. Asas atau ciri, aspirasi dan program Partai Politik tidak bertentangan dengan pancasila:

c. Keanggotaan Partai Politik bersifat terbuka untuk setiap warga negara Republik Indonesia yang telah mempunyai hak pilih

d. Partai politik tidak boleh menggunakan nama atau lambang yang sama dengan lambang negara asing. Bendera Negra Kesatuan Republik

12 Ibid, hal. 47 
Indonesia sang Merah Putih, Bendera kebangsaan negara asing, gambar perorangan dan nama serta lambang partai lain yang telah ada. ${ }^{13}$

Persyaratan dan procedural pendirian partai politik diatur didalam pasal 4 ayat (1), (2) dan (3) yang mengatur bahwa partai poltik didirikan degan akta notaris dan didaftarkan pada departemen kehakiman RI. Partai Politik yang telah memenuhi persyaratan pembentukan kemudian di sahkan sebagai badan hukum dan diumumkan didalam berita Negara Republik Indonesia.

Didalam bab VI Undang-Undang Nomor 2 Tahun 1999, diatur juga terkait dengan Persyaratan keuangan partai politik, ketentuan keuangan partai partai politik adalah meliputi sumber pendanaan, bentuk organisasi, besaran maksimal penerimaan, laporan keuangan. Pasal 12 ayat 1 sumber keuangan partai bersumber dari:iuran anggota, sumbangan dan usaha lain yang sah. Pasal 12 ayat (2) juga menyebutkan terkait dengan penerimaan bantuan tahunan dari anggaran negara dan ditetapkan berdasarkan perolehan suara dalam pemilihan umum sebelumnya dan kemudian partai dilarang untuk menerima bantuan dari negara atau pihak asing.

Didalam pasal 14 ayat (1), (2), (3), diatur terkait dengan batasan maksimal sumbangan yang dapat diterima oleh partai. Adapun jumlah sumbangan yang dibatasi oleh adalah sebesar Rp.15.000.000 (lima belas juta) didalam setahunnya. Adapun jumlah sumbangan dari badan hukum yang lain seperti perusahaan dibatasi sebesar Rp. 150.000.000 (seratus lima puluh juta) dalam setahunnya. Partai juga dapat menerima sumbangan berupa barang yang jumlahnya disesuaikan dengan jumlah sumbangan yang berupa uang.

Keuangan partai politik juga harus dilaporkan sebagaimana diatur didalam pasal 15 aayat (1) dan (2). Partai diwajibkan untuk melaporkan daftar penyumbang, jumlahnya dan membuat laporan keuangan 15 hari sebelum dan 30 hari sesudah pemilihan umum kepada Mahkamah Agung.

Didalam Undang-undang Nomor 2 Tahun 1999 juga disebutkan terkait dengan larangan, pengawasan dan pembubaran partai politik yaitu diatur didalam Pasal 16 huruf a yang mengatakan larangan Partai politik untuk menganut, menyebarkan, mengembangkan ajaran atau paham Komunisme/Marxisme/ Leninismen dan ajaran lain yang bertentangan dengan Pancasila. Mahkamah Agung menurut Pasal 17 ayat (1), (2), (3) dan (4) dan Pasal 18 ayat (1), (2) dan (3) Undang-Undang Nomor 2 Tahun 1999 berwenang untuk mengawasi,membekukan, membubarkan serta menjatuhkan sanksi administratif berupa penghentian bantuan anggaran negara kepada partai, mahkamah agung juga berwenang untuk mencabut hak partai untuk mengikuti pemilihan umum apabila melanggar ketentuan tersebut.

3.2.2. Undang-Undang Nomor 31 Tahun 2002

Undang-Undang Nomor 31 Tahun 2002 Merupakan Undang_undang yang menggantikan Undang-Undang Nomor 2 Tahun 1999 terkait dengan kebijakan penyederhanaan partai politik di kemukakakn didalam penjelasan UndangUndang Nomor 31 Tahun 2002. Adapun ketentuan tentang persyaratan penyederhanaan partai politik menurut Undang-Undang Nomor 31 Tahun 2002 terdapat didalam Bab II Pasal 2, 3, dan Pasal 4. Didalam Pasal 2 ayat (1) dan (2) disyaratkan bahwa partai politik dibentuk dan didirikan oleh minimal 50 orang

${ }^{13}$ Lihat Dalam Undang-Undang Nomor 2 Tahun 1999 Pasal 2 ayat (2) 
Warga Negara Indonesia (WNI) yang berusia 21 tahun dengan memuat anggaran dasar dan anggaran rumah tangga dengan akta notaris serta kepengurusan ditingkat nasional.berdasarkan Pada Pasal 2 ayat (3), untuk terdaftar sebagai badan hukum partai politik harus memenuhi persyaratan yakni:memiliki akta notaris yang sesuai dengan UUD 1945 dan peraturan Perundang-undangan yang lainnya, memiliki kepengurusan minimal 50\% dari jumlah provinsi, 50\% dari jumlah Kabupaten/kota di dalam tiap-tiap provinsi bersangkutan dan 25\% dari jumlah keseluruhan kecamatan di setiap Kabupaten/kota memiliki nama, lambang dan tanada gambar yang idak sama dengan nama.lambang dan tanda gambar partai politik lain serta sudah memiliki kantor yang berkedudukan tetap. Prosedur pendaftaran partai politik menjadi badan hukum diatur pada pasal 3 ayat (1), (2) dan (3). Partai politik yang persyaratannya sudah terpenuhi di daftarkan ke departemen Kehakiman selambat-lambatnya 30 hari setelah penerimaan pendaftaran Menteri Kehakiman kemudian mengesahkan Partai politik menjadi badan hukum dan diumumkan dalam berita Negara Republik Indonesia.

Dalam pasal 5 ayat (1) dan (2) ditentukan bahwa asas dan ciri partai politik tidak boleh bertentangan dengan pancasila dan Undang-Undang Dasar 1945. Adapun peraturan terkait keuangan partai politik diatur dalam Bab IX yang terdiri dari sumber pendanaan,batasan minimum penerimaan. Mengenai kewajiban tentang laporan keuangan diatur diadalam pasal 9 huruf h,idan j yaitu: sumber pendanaan partai politik terdiri dari iuran anggota, sumbangan yang sah menurut hukum dan bantuan negara yang diberikan dari anggaran nengara sesuai perolehan kursi di DPR. Keuangan partai politik di wajibkan untuk membuat pembukuan, daftar penyumbang, jumlah sumbangan yang bersifat terbuka kepada masyarakat dan pemerintah. Laporan keuangan juga harus dibuat secara berkala per tahun disampaikan kepada Komisi Pemilihan Umum yang sebelumnya sudah diaudit oleh akuntan publik. Partai juga memiliki kewajiban untuk memiliki rekening khusus dana kampanye pemilihan umum serta wajib menyerahkan laporan hasil keuangan yang merupakan hasil audit akuntan publik kepada KPU paling lambat 6 bulan setaelah hari pemungutan suara.

Didalam Undang-Undang Nomor 31 Tahun 2002 juga mengatir terkait larangan dalam Bab X yaitu mengenai nama dan lambang partai,kegiatan partai sumbangan/penerimaan, larangan mendirikan badan usaha dan larangan untuk menganut ajaran komunisme/marxisme-leninisme.

4.2.3. Undang -Undang Nomor 2 Tahun 2008

Undang-undang Nomor 2 Tahun 2008 adalah penganti undang-undang Nomor 31 Tahun 2002 ttentang partai politik yang belum optimal mengakomodasi dalam setiap perkembangan serta dinamika masyarakat yang menuntut peran partai politik dalam kehidupan berbangsa dan bernegara.

Pendirian partai politik berdasarkan pasal 2 ayat (1), (2) (3) dan (4) bahwa partai politik didirikan oleh 50 orang WNI yang sudah berusia 21 tahun dengan akta notaris yang menyertakan $30 \%$ keterwakilan perempuan dan memuat AD serta ART dan kepengurusan ditingkat pusat. Anggaran Dasar partai memuat tentang asas dan ciri partai, visi dan misi, nama, lambang dan tanda gambar, tujuan dan fungsi partai organisasi, tempat kedudukan dan pengambilan keputusan partai keuangan partai serta peran partai dalam pendidikan politik. Pendaftaran dan prosedur penetapan partai politik sebagai badan hukum diatur didalam pasal 3 dan 4. Untuk menjadi sebuah badan hukum partai politik mempunyai akta notaris 
pendirian, nama dan lambang/ tanda gambar yang tidak sama dengan yang lai memiliki kantor tetap dam memiliki kepengurusn minimal $60 \%$ dari jumlah provinsi, 50\% dari jumlah kabupaten/kota provinsi yang bersangkutan dan $25 \%$ dari kecamatan di kabupaten/kota yang bersangkutan dan harus memiliki rekening sendiri atas nama partai. Berdasarkan Pasal 9, asas partai politik tidak boleh bertentangan dengan pancasila dan UUD 1945, partai politik dapat mencamtumkan ciri dari sebuah ideology partai yang tidak bertentangan dengan pancasila dan UUD 1945.

Mekanisme yang dilakukan dalam hal pemailitan partai politik adalah sama dengan mekanisme pemailitan terhahadap Perseroan Terbatas (PT) dengan alasan bahwa partai politik dan Perseroan Terbatas adalah sama-sama berbadan hukum.

Partai politik bisa dipailitkan sebagaimana Perseroan terbatas jika partai politik memenuhi syarat kepailitan yang telah diatur dalam Undang-undang kepailitan. Namun dalam Undang-undang kepailitan belum mengatur secara khusus tentang pemailitan partai politik, karena tidak menutup kemungkinan partai politik bisa melakukan syarat-syarat kepailitan pada badan hukum. Walaupun telah kita ketahui bahwasanya partai politik dikaregorikan sebagai badan hukum publik yang di lihat dari sistem pembentukannya melalui perkumpulan orang yang memiliki pemikiran yang sama dan tujuan yang sama dalam organisasi dan Perseroan terbatas dikategorikan sebagai Badan hukum privat yang sistem pembentukannya melalui individu atau perseorangan.

Hal ini juga dibahas dalam buku Jimly asshiddiqie, bahwa lembagalembaga negara yang menyandang predikat badan hukum publik itu sendiri tetap dapat bertindak dilapangan badan hukum privat seperti menyewa rumah atau membeli alat-alat kantor dan lain sebagainya. Berbagai transaksi dilapangan hukum perdata itu tidak menyebabkan bahwa badan hukum publik bisa berubah menjadi badan hukum privat atau perdata. Sebaliknya, badan hukum privat seperti persero atau koperasi dapat saja terlibat dalam melakukan aktivitas dilapangan hukum publik. Misalnya, sebagai badan hukum melakukan pelanggaran di bidang hukum administrasi negara ${ }^{14}$. Bahwa partai politik bisa saja melakukan tindakan yang menyebabkan partai politik tersebut bisa dipailitkan, misalnya apabila partai politik meminjam dana kepada suatu Bank, dan partai politi (kreditur) tidak bisa menutupi hutang tersebut pada Bank ( Debitur ), maka disitulah unsur-unsur kepailitan tepenuhi .

Maka pemerintah harus membentuk peraturan terkait dengan konsep pemailitan partai politik atau merubah undang - undang terkait dengan partai politik berdasarkan bentunya sebagai badan hukum agar supaya partai politikjuga dapat untuk dipailitkan dengan catatan adalah untuk menjadikan sistem kepartaian di Indonesia menjadi sitem multipartai sederhana sesuai dengan penjelasan Unadng-Undang Nomor 2 Tahun 2011 tentang partai politik.

Sebagai suatu organisasi nasional yang bergerak di ranah politik, Partai Politik memiliki hak dan kewajiban yang sama berdasarkan Undang-Undang No 2 Tahun 2011. Beberapa hak yang dimiliki oleh partai politik diantaranya adlah memproleh perlakuan yang sama, sederajat, dan adil dari negara. Selain hal tersebut partai

${ }^{14}$ Jimly Asshiddiqie , perkembangan \& konsolidasi lembaga Negara pasca reformasi , sinar grafika, Jakarta 2010, hal 72 
politik juga mempunyai hak unutk memdapat bantuan keuangan yang diproleh dari Angggaran Pendapatan dan Belanja Negara/Anggaran Pendapatan dan Belanja Daerah yang sesuai dengan peraturan perundang-undangan.

Kedudukan partai poltik sebagai badan hukum yang diatur didalam pasal 3 Undang-Undang Nomor 2 Tahun 2011, ada karena diciptakan atau diwujudkan dengan melalui proses hukum (created by legal process) sesuai dengan ketentuan yang diatur didalam peraturan perundang-undangan yang ada. Oleh sebab itu partai politik disebut sebagai badan hukum sesuai dengan teori kenyataan yuridis yang memahami keberadaan dan kapasitas dari badan hukum sebagai subjek hukum yang dapat melakukan perbuatan serta memberikan hak dan kewajiban kepada badan hukum sehingga badan hukum menjadi person standi in judicio yang berarti subjek hukum mandiri.

Adapun tindakan partai politik sebagai badan hukum yang dinyatakan pailit akan mengubah tatanan dari sistem kepartaian yang ada di Indonesia sekarang ini. Pemailitan partai politik adalah sebagai salah satu upaya dalam menjadikan sitem kepartaian di Indonesia menjadi sistem multipartai sederhana. Didalam pendirian partai politik juga seperti layaknya pendirian sebuah Perseroan Terbatas pembaningkan kepailitan partai politik kepada sebuah perseroan terbatas

perbedaannya adalah bahwa partai politik tidak dapat melaksanakan atau menjalankan usaha sebagaimana diatur didalam undang-undang Nomor 2 Tahun 2011 tentang partai politik, namun esensi dari kepailitan partai politik tidak diatur didalam undang-undang nomor 37 Tahun 2004 Tentang kepailitan. Hal ini bukan berati tidak ada kemungkinan bahwa partai politik tidak akan di pailitkan. Hal ini setelah mengkaji terhadap peraturan KPU Nomor 15 Tahun 2014 Pasal 14 huruf k yang berbunyi:

surat keterangan dari pengadilan Negeri/Niaga tempat domisisli bakal calon yang menerangkan Bakal Pasangan Calon:

1. Tidak sedang dinyatakan pailit berdasarkan putusan pengadilan;

2. Tidak sedang memiliki tanggungan utang secara perorangan dan/atau secara badan hukum yang menjadi tanggung jawabnya yang merugikan keuangan negara, dan;

3. Tidak pernah dijatuhi pidana penjara berdasarkan putusan pengadilan yang telah mempunyai kekuatan hukum tetap kareana melakukan tindak pidana yang diancam dengan pidana penjara 5(lima) tahun atau lebih. ${ }^{15}$

Dan berdasarkan Undang-Undang Nomor 7 Tahun 2017 pasal 169. Hal tersebut seharusnya berlaku terlebih dahulu kepada partai politik yang berpartisipasi dalam kontestasi politik yang mengusungkan bakal calon presiden dan wakil presiden, karena calon presiden dan wakil presiden berdasarkan Undang-Undang Nomor 7 Tahun 2017 Tentang Pemilihan Umum pasal 222 bahwa:

Pasangan calon diusulkan oleh partai politik atau Gabungan Partai Politik peserta pemilu yang memenuhi persyaratan perolehan kursi paling sedikit $20 \%$ (dua puluh persen) dari jumlah kursi DPR atau memproleh $25 \%$ (dua puluh lima pesen) dari suara sah secara nasional pada pemilu anggota DPR sebelumnya.

Pasangan calon presiden dan wakil presiden di usung oleh partai politik dan gabungan partai politik. Akibat hukum dari pernyataan pailit suatu partai

\footnotetext{
${ }^{15}$ Lihat dalam Peraturan Komisi Pemilihan Umum Nomor 15 Tahun 2014
} 
politik demi hukum kehilangan setiap haknya terhadap pengelolaan keuangannya, hak unuk mengurus secara mandiri organisaninya, partai politik tidak boleh melakukan kepengurusan Parpol dengan sekehendaknya sendiri/mandiri dan perbuatan-perbuatan yang dialkukan dengan itikad buruk untuk merugikan negara, partai politik yang dinyatakan pailit selanjutnya akan kehilanganhaknya dalam mengikuti pemilihan umum untuk memilih anggota Dean Perwakilan Rakyat, Dewan Perwakilan Rakyat Daerah, Presiden dan Wakil Presiden serta kepala daerah dan wakli kepala daerah, partai politik yang dinyatakan pailit juga tidak dapat membentuk fraksi di tingkat Majelis Permusyawaratan Rakyat, Dewan Perwakilan Rakyat, Dewan Perwakilan Rakyat Daerah Provinsi, Dewan Perwakilan Rakyat Daerah Kabupaten/Kota, selain itu partai politik dilarang untuk mengajukan calon untuk mengisi keanggotaannya DPR dan DPRD, dan dilarang mengusulkan pergantian antar waktu DPR dan DPRD, anggota partai politik yang pailit dan duduk dikursi DPR/DPRD otomatis berhenti tanpa mengusulkan pemberhentian, partai politik juga kehilangan haknya untuk mengusulkan calon presiden dan wakil presiden, calon gubernur dan wakil gubernur, bupati dan wakil bupati serta calon walikota dan wakil walikota, serta yang terpenting dari partai politik yang sudah dinyatakan pailit adalah kehilangan atau penghentian yang diproleh dari bantuan keuangan negara dari Anggaran Pendapatan dan Belanja Negara/ Anggaran Pendapatan dan Belanja Daerah.

kepailitan suatu partai politik mengakibatkan seluruh benda yang dimiliki oleh partai berada dalam sitaan umum sejak putusan pailit diucapkan yaitu diantaranya adalah:

a. benda yang berhubungan dengan pengurusan dan kegiatan kepartaian

b. segala sesuatu yang diproleh dari iuran angota, sumbangan badan hukum yang lain, bantuan negara yang berbentuk APBN/APBD.

Partai politik yang dinyatakan pailit akan kehilangan segala hak perdata untuk menguasai dan mengurus keuangan partai politik yang telah dimasukkan kedalam harta pailit.

4.4.1. Akibat Hukum Putusan Pailit Terhadap Kepengurusan Partai Politik

Partai politik adalah badan hukum yang terdaftar di kementerian dan didirikan serta berkedudukan dalam melakukaan kegiatan kepartaian di wilayah hukum negara Republik Indonesia dalam menyelenggarakan agenda atau kegiatan serta kepentingan politik tertentu.

Berbeda dengan perseroan terbatas (PT) partai politik tidak dikelola oleh Kurator umum namun partai politik dikelola oleh curator yang ditunjuk langsung oleh Mahkamah Konstitusi dalam menjalankan tugasnya di dalam partai politik yang sedang atau dinyatakan pailit, setelah kemudian kurator menentukan pilihannya di dalam memaksimalkan nilai pailit, dengan cara menjual asset serta sisa keuangan partai politik, maka selanjutnya dilakukan pengembalian aset kepada negara dan kepada kreditur setelah aset partai politik terjual menjadi bentuk tunai.

Partai politik bukanlah makhluk hidup sebagaimana manusia, parpol tidak mempunyai daya piker dan kehendak, oleh karenanya partai politik tidak dapat melakukan perbuatan-perbuatan hukum sendiri. partai politik harus bertindak dengan perantaran orang-orang biasa, akan tetapi orang yang bertindak didalam 
partai politik (kepengurusan) itu tidak bertindak untuk dirinya melaikan untuk dan atas pertanggung gugat sebagai badan hukum (partai politik).

Kepailitan partai politik sebagai suatu lembaga terjadi karena kesalahan atau kelalaian dari kepengurusan partai mak setiap anggota pengurus partai pusat ataupun yang ada di daerah bertanggung jawab secara tanggung renteng atas kerugian tersebut. Adapun kewenangan pengurus partai demi hukum berakhir dengan di pailitkannya partai tersebut dimana tanggung jawab kepengurusan dialihkan kepada kurator sepanjang kewenangan berkaitan dengan kepengurusan dan perbuatan kepemilikan keuangan partai politik

4.4.2. Akibat Hukum Putusan Pailit Partai Politik Terhadap Pihak Ketiga

Pendekatan institusioanal memandang bahwa partai politik sebgai lembaga yang memiliki struktur dan fungsi untuk mencapai tujuan. Namun partai yang dinyatakan pailit mempunyai peranan untuk menyelsaikan bermacam-macam tagihan yang kemudian diajukan oleh kreditur yang masing-masing mempunyai kepentingan yang berbeda. Proses kepailitan mempunyai sasaran yang utama dalam mengatur pertentangan-pertentangan yang saling berkaitan diantaran beberapa kelompok yang berbeda dan masing-masing mempunyai klaim terhadap partai politik yang pailit.

Akibat-akibat hukum dari putusan pailit terhadap keuangan partai politik adalah:

1. putusan pemailitan dapat dijalankan terlebih dahulu

putusan pengadilan dapat dijalankan terlebih dahulu, walaupun terhadap putusan pailit dan dilakukan suatu upaya hukum lebih lanjut. Apabila putusan pailit dibatalkan sebagai akibat dari adanya proses atau upaya hukum tersebut maka segaka perbuatan yang dilakukan oleh kurator dalam menjalankan tugasnyasebelum kurator menerima pemberitahuan tentang putusan pembatalan, mak tetap dan mengikat bagi parpol.

2. Sitaan Umum

Keuangan partai politik yang masuk didalam keuangan yang dinyatakan pailit merupakan sitaan umum, sita umum terhadap keuangan yang pailit tidak memerlukan suatau tindakan khusus untuk melakukan sitaan tersebut. Namum segala keuangan partai yang dinyatakan pailit berada dalam status dihentikan dari segala transaksi dan perbuatan hukum yang kain termasuk dana kampanye sampai dengan keuangan tersebut di urus atau dikelola oleh kurator.

3. Kehilanagan Wewenang Terhadap Keuangan Dan Kepengurusan Partai

Partai politik yang pailit demi hukum kehilangan haknya untuk mengurus segala sesuatau yang berkaitan tentang keuangan partai politik dan juga kehilangan haknya dalam kepengurusan partai politik namun anggota dan mantan pengurus partai politik tidak akan kehilangan hak-hak sebagai warga negara seperti hak politik dan hak privat lainya yang melekat kepada setiap waga negara Republik Indonesia.

4. Penetapan Putusan Pengadilan Sebelumnya

Pernyataan pailit juga berakibat segala penetapan pelaksanaan pengadilan terhadap setiap bagian dari keuangan partai yang di mulai sebelum terjadinya 
kepailitan, harus diberhentikan seketika dan sejak itu tidak ada suatu putusan yang dapat dilaksanakan diluar wewenang pengadilan.

5. Hubungan Pengurus Dan Anggota Partai Politik Yang Pailit

Anggota dan pengurus partai politik dapatberhenti dari keanggotaan dan kepengurusan kepartaian dan sebaliknya kurator dapat memberhentikan anggota parpol dalam jangka waktu menurut persetujuan dan dalam ketentuan peraturan perundang-undangan yang akan dibuat nantinya.

Hal tersebutlah yang akan terjadi kemudian setelah adanya kebijakan penyerderhanaan partai politik melalui mekanisme/konsep mempailitkan partai politik sehingga dalam hal menjadikan sitem kepartaian diindonesia stabil dan menuju sistem multi partai sederhana ssuai dengan penjelasan Undang-Undang Nomor 2 Tahun 2011 Tentang perubahan atas Undang-Undang Nomor 2 Tahun 2008 Tentang Partai Politik.

Pengatura pembubaran partai politk yang diatur didalam ketentuan UndangUndang No 31 Tahun 2002 menekankan kepada alasan bagaimana sebuah partai politik itu bubar, seperti menganut,menyebarkan ajaran atau paham Komunisme/marxisme-leninisme. Ketentuan ini dianggap sebgai pelanggaran ideology yang dapat dijadkan sebagai alasan yuridis dalam pembubaran partai politik.

Menurut pasal 27 ayat (2) terdapat sanksi yang diperutukkan bagi partai politik yaitu adalah pembekuan partai politik. Menurut Jimly Asshiddiqie, alasan pembekuan partai politik dalam Pasal 19 ayat (2) Undang-Undang Nomor 31 Tahun 2002 dapat dipergunakan sebagai alasan untuk mengajukan pembubaran partai politik kepada Mahkamah Konstitusi, dengan demikian, terdapat 3 skenario pembubaran parti politik dikaitkan dengan adanya proses pembekuan. ${ }^{16}$

Skenario kedua adalah pemerintah dapat saja langsung mengajukan permohonan pembubaran partai politik ke Mahkamah Konstitusi tanpa melalui proses pembekuan. Hal itu dapat dilandasi pemikiran bahwa pembekuan dimaksudkan untuk memberi kesempatan kepada partai politik untuk memperbaiki diri. Oleh karena itu, jika memang pemerintah berpendapat bahwa partai yang bersangkutan sudah tidak mungkin memperbaiki diri, dapat saja langsung mengajukan permohonan pembubaran partai politik ke Mahkamah Konstitusi. ${ }^{17}$

Scenario ketiga adalah dalam kasus partai politik telah diputus dibekukan oleh peradilan negeri berdasarkan gugatan pemerintah. Selanjutnya partai politik yang bersangkuta mengajukan kasasi ke Mahkamah Aggung yang ternyata membatalkan putusan pengadilan negeri, sehingga partai politik tidak dibekukan. Terhadap kasus tersebut pemerintah tetap dapat mengajukan permohonan pembubaran partai politik ke Mahkamah Konstitusi. ${ }^{18}$

Undang -Undang Nomor 24 Tahun 2003 Tentang Mahkamah Konstitusi telah mengatur secara umum mengenai perihal pembubaran partai politik yang menjadi domain kewenangan Mahkamah Konstitusi. Di dalam Pasal 10 ayat (1)

16 Jimly Asshiddiqie dalam Erlanda Juliansyah Putra., Gagasan Pembubaran Partai Politik Korup Di Indonesia,. hal 144

${ }^{17}$ Ibid., hal 132

${ }^{18}$ Ibid., hal 133 
huruf c disebutkan bahwa Mahkamah Konstitusi berwenang mengadili pada tingkat pertama dan terakhir yang putusannya bersifat final untuk memutus pembubaran partai politik. Ketentuan tersebut memiliki pengertian bahwa sesungguhnya hanya Mahkamah Konstitusilah yang diberikan kewenangan secara absolut sebagai satu-sastunya kekuasaan kehakiman yang berwenang melakukan pembubaran partai politik di Indonesia. ${ }^{19}$

Pengaturan terkait dengan pembubaran partai politik diatur pada bagian kedua dan kesepuluh Hukum Acara Mahkamah Konstitusi, disebutkan pada bagian kedua Undang-Undang Nomor 24 Tahun 2003 pada pasal 30 bahwa permohonan yang dibuat pemohon dalam hal ini adalah peerintah sebgaimana yang dijelaskan di dalam bagian kesepuluh tentang pembbaran partai politik pada Pasal 68 ayat (1) Undang-Undang Nomor 24 Tahun 2003 wajib dibuat dengan uraian yang jelas terutama mengenai yang menjadi dasar permohonan pemohon terhadap suatu partai politik.

Di dalam Pasal 68 Undang-Undang tersebut didalam permohonannya, pemohon diwajibkan untuk menguraikan secara jelas mengenai ideology, asas, tujuan, program, dan kegiatan partai politik yang diangap bertentangan dengan Undang-Undang Dasar Negara Republik Indonesia Tahun 1945. Kemudian pada Pasal 69 dijelaskan bahwa Permohonan tersebut kemudian dicatat ke dalam buku registrasi perkara konstitusi paling lambat 7 (tujuh) hari kerja sejak permohonan tersebut dictat di dalam buku regoistrasi perkara konstitusi.

Mahkamah Konstitusi wajib memutus mengenai permohonan atas pembubaran partai politik, dengan jangka waktu paling lambat (enam puluh) hari sejak permohonan tersebut dicatatkan ke dalam Buku Registrasi Perkara Konstitusi. Kemudian disampaikan kepada partai politik yang bersangkutan dengan menyertakan pelaksanaan putusan pembubaran partai politik yang bersangkutan dengan menyertakan pelaksanaan putusan pembubaran partai politik dengan membatalakna pendaftaran pada pemerintah patau diumukan oleh pemerintah dalam Berita Negara Republik Indonesia dalam jangka waktu paling lama 14 hari sejak putusan diterima.

Ketentuan tersebut menujukkan bahwa putusan Mahkamah Konstitusi bersifat deklaratoir dengan menyatakan bahwa partai politik bubar atau dibubarkan sejak putusan itu diucapkan dalam siding pleno terbuka. Berate bahwa pendaftaran tersebut pada pemerintah dan stautus pendaftraannya sebgai badan hukum di pisah. Dilihat dari ketentuan pasal 73 ayat (1) itu tidak dikatakan oleh pemeritah, melainkan pada pemerintah artinya bahwa Mahkamah Konstitusilah yang membubarkan partai politik dari stautsuya sebgai bdan hukum yang terdaftar di pemerintah.

Peratuan mengenai ketentuan pembubaran partai politik didalam Undangundang Nomor 24 tahun 2003 dinilai belum lengkap sehingga diatur kembali didalam peraturan Mahkamah Konstitusi Nomor 12 Tahun 2008 yang memuat pedoman dalam beracara dalam pembubaran partai politk yang terdiri dari 12 Pasal yang kemudian megatur terkait dengan pembubaran partai politik.

Pemohon adalah pemerintah yang dapat diwakili oleh Jaksa Agung atau Menteri yang mendapat tugas dari presiden. Sedangkan termohon adalah partai

\footnotetext{
${ }^{19}$ Ibid., hal 134
} 
politik yang diwakili oleh partai politik yang dimohonkan untuk dibubarkan dan dapat diwakili oleh kuasa hukumnya.

Apabila kemudian permohonan dikabulkan hakim mahkamah kemudian akan menyatakan membubarkan dan membatalkan dan membatalkan status badan hukum partai politik yang dimohonkan pembubaran. Selanjutnya kemudian memerintahkan kepada pemerintah untuk:

a. Menghapus partai politik yang dibubarkan dari daftar pemerintah paling lambat dalam jangka waktu 7 (tujuh) hari kerja sejak putusan Mahkamah diterima;

b. Mengumumkan putusan Mahkamah dalam berita negara Republik Indonesia paling lambat 14 (empat belas hari) sejak putusan diterima.

Setelah permohonan dikabulkan dan diterima, maka kakibat hukum yang timbul kepada si termohon dalam hal ini partai politik adalah:

a. Adanya pelarangan Hak hidup terhadap partai poliik dan penggunaan symbol-siimbol partai tersebut di seluruh Indonesia;

b. Adanya pemberhentian terhadap seluruh anggota DewN Perwakilan Rakyat dan Dewan Perwakilan Rakyat Daerah yang berasal dari partai politik yang dibubarkan;

c. Adanya pelarangan terhadap mantan pengurus partai politik yang dibubarkan untuk melakukan kegiatan politik;

d. Pengambilalihan oleh negara atas kekayaan partai politik yang dibubarkan.

Putusan Mahkamah kemudian disampaikan kepada pemerintah sebagai pemohon, termohon KPU, DPR, Mahkamah Agung, Kejagung, dan Kepolisian negara Indonesia. Hukum acara pembubaran partai politik pada Undang -Undang Nomo 24 Tahun 2003 dinilai masih belum lengkap sehingga kemudian di perbharui dengan peraturan MK nomo 12 Tahun 2008. Pengaturan tentang mahkamah konstitusi mengalami perubahan seirng dengan perubahan UndangUndang Nomor 8 Tahun 2011 namun untuk ketentuan pembubaran partai politik tidak mengalami perubahan sehingga tetap menggunakan peraturan induknya yakni Undang-Undang Nomor 24 Tahun 2003 Tentang Mahkamah Konstitusi.

Seiring dengan perkembangan sistem ketatanegaraan di Indonesia peraturan terkait partai politik mengalami perubahan yakni melalui UndangUndang Nomor 2 Tahun 2008 tentang Partai politik dan Undang -Undang Nomor 2 Tahun 2011 Tentang Parttai politik perbedaan yang cukup signifikan di daantara dua peraturan perundang-undangan tersebut adalah terkait dengan sumbangan yang dapat di berikan kepada partai politik di dalam pasal 3 Undang-Undang Nomor 2 Tahun 2008 klasifikasinya adalah:

a. Perseorangan anggota partai politik pelaksanaannya diatur dalam AD dan ART;

b. Perseorangan bukan anggota partai politik, paling banyak senilai Rp 1.000.000.000,00 (satu miliar rupiah) per orang dalam waktu 1 (satu) tahun anggaran; dan

c. Perusahaan dan/atau badan usaha, paling banyak senilai Rp. 4.000.000.000,00 (empat miliar rupiah) per perusahaan dan/atau badan usaha dalam waktu 1 (satu) tahun anggaran. 
Dalam hal pembubaran partai politik, ketentuan yang terdapat didalam Undang-Undang ini tidak jauh berbeda dengan Undang-Undang sebelumnya. Dan mekanismenya menggunakan mekanisme yang sama dengan Undang-Undang No 31 Tahun 2002.

Perbedaan yang terdapat didalamketetuan Undang-Undang Nomor 2 Tahun 2008 adalah adanya perubahan nomenklatur pengenaan sanksi yang disebutkan di dalam pasal 47 yang menyebutkan bahwa pelanggaran terhadap ketentuan yang dimaksud dalam Pasal 13 huruf $\mathrm{h}$ yang mengatur tentangn pembukuan daftar penyumbang dan jumlah sumbangan dapat dikenakan sanksi administratif berupa teguran oleh pemerintah, yang dimana pada pengaturan sebelumnya di dalam Pasal 26 Undng-Undang Nomor 31 Tahun 2002 teguran tersebut dilakukan secara terbuka oleh Komisi Pemilihan Umum. Komisi Pemilihan Umum kemudian hanya diberikan kewenangan memberikan teguran dalam hal kepemilikan rekening khusus dan dana kampanye pemilihan umum.

Selanjutnya adalah perbedaan dalam hal pembekuan partai politik yang partai politik melakukan pelanggaran terhadap ketentuan Pasal 40 ayat (2) mengenai larangan terhadap kegiatan yang bertentangan dengan Undang-Undang Dasar dan melakukan kegiatan yang membahayakan keutuhan dan keselamatan Negara Kesatuan Republik Indonesia dapat dikenakan sanksi administratif berupa pembekuan sementara sesuai dengan tingkatan pelanggarannya aitu paling lama 1 (satu) tahun dengan penambahan ketentuan di dalam Pasal 48 ayat (3) UndangUndang Nomor 2 Tahun 2008 yang menjelaskan bahwa apabila kemudian hari partai tersebut melakukan pelangaran yang sama maka partai tersebut dapat dibubarkan melalui putusan Mahkamah Konstitusi. Mengenai ketentuan pembubaran partai politk tetap tidak ada perubahan yaitu dikenkan kepada partai yang mengembangkan dan menyebarluaskan ajaran-ajaran komunisme/marxismeleninisme kepada anggotanya.

Kemudian perubahan memgenai ketentuan partai politik di lakukan oleh pemerintah dengan mengundangkan Undang-Undang Nomor 2 Tahun 2011 perbedaan yang mencolok dengan peraturan sebelumnya adalah dalam hal presentase persyaratan partai politkk untuk dijadikan badan hukum dan tentang penentuan jumlah sumbangan yang dapat diperuntukkan kepada partai politik.

Penentuan presentase pendirian partai politik pemerintah menetapkan standarisasi kepengurusan pada setiap provinsi dengan jumlah keengurusan paling sedikit $75 \%$ dari jumlah kabupaten/kota pada setiap provinsi dan 50\% dari jumlah kabupaten/kota pada setiap provinsi di Indonesia.

Kedua adalah penentuan terkait dengan jumlah sumbangan yang diperuntukkan untuk Partai Politik dalam Pasal 35 Undang-Undang Nomor 2 Tahun 2011 disebutkan bahwa sumbangan yang diterima oleh partai politik dapat bersal dari:

a. Perseorangan anggota partai politik yang pelaksanaannya diatur dalam AD dan ART;

b. Perseorangan bukan anggota partai politik, paling banyak senilai Rp 1.000.000.000,00 (satu miliar rupiah) per orang dalam waktu 1 (satu) tahun anggaran; 
c. Perusahaan dan/atau badan usaha, paling banyak senilai Rp. 7.500.000.000,00 (tujuh miliar lima ratus juta rupiah) per perusahaan dan/atau badan usaha dalam waktu 1 (satu) tahun anggaran.

Dengan ketentuan sebelumnya presentase kenaikan besar iuran yang diberikan oleh perusahaan/badan usaha meningkat dari sebelumnya Rp. 4.000.000.000,00 (empat miliar rupiah) menjadi Rp.7.500.000.000,00 (tujuh miliar lima ratus juta rupiah) dengan peningkatan selisih Rp.3.500.000.000,00 (tiga miliar lima ratus juta rupiah).

Partai politik adalah cerminan dari kebebasan berserikat dan berkumpul namun kebebasan juga memerlukan batasan-batasan yang diperlukan dalam masyarakat demokratis demi keamanan nasional dan keselamatan warga negara, untuk mencaegah kejahatan, serta untuk melindungi hak dan kebebsan yang lain.

Sejak MK berdiri da diberi kewenangan untuk membubarkan partai politik, belum pernah ada partai politik yang dibubarkan oleh MK. Hal ini mereflesikan dua sebab, yaitu alasannya terbatas pada hal yang terkait dengan melawan ideology, konstitusi dan NKRI serta pemohonya hanya terbatas pada pemerintah. Berkenaan dengan alasan pembubaran, kenyatannya di Indonesia secara formal, tidak ada lagi partai politim yang berani melawan idologi pancasila UUD NRI 1945, dan NKRI. Fakta di lapangan justru menujukan bahwa sebenaranya bentuk-bentuk pelanggaran yang dilakukan oleh parai politik lebih kepada pelanggaran yang sifatnya tidak diatur dalam peraturan perundangundangan, padalah tindangan tersebut telah melanggar peraturan perundangundangan dan berdampak sistemik terhadap penyelenggaraan negara. ${ }^{20}$

Hal tersebut yang melatar belakangi gagasan terkait dengan pemailitan dilanjutkan dengan pembubaran partai politik dan juga karena peran tunggal pemerintah sebagai pemohon pembubaran partai politik.

4.2.1. Ius Contituendum Pembubaran Partai Politik Pailit Di Indonesia

Berkenaan dalam pembahasan terkait dengan ius contituendum prosedur pembubaran partai politik di Indonesia, penulis telah membaginya menjadi 3 (tiga) tahapan, pertama adalah tahapan Peradilan Niaga, kedua tahapan pengajuan permohonan kepada Mahkamah Konstitusi, dan ketiga adalah tahap persidangan di Mahkamah Konstitusi.

\section{A. Pengadilan Niaga}

Pada umumnya dalam hal pembubaran partai politik pengadilan yang berwenang adalah Mahkamah Konstitusi (MK) atau Mahkamah Agung (MA). Hal itu terkait dengan putusan pembubaran yang bersifat final dan mengikat, kecuali di hunggaria yang apat di ajukankasasi kepada General Assembly Of The College Of Attorneys. ${ }^{21}$ Berdasarkan ketentuan di beberapa negara, pembubaran partai politik lebih banyak merupakan wewenang Mahkamah Konstitusi.Tidak terkecuali di Indonesia. Pasal 24 C ayat (1) UUD NRI 1945 dan Pasal 10 ayat (1) huruf d Undangundang Mahkamah Konstitusi menyebutkan bahwa Mahkamah Konstitusi adalah satu-satunya lembaga yang ditunjuk untuk memutus pembubaranpartai politik di Indonesia. namun dalam gagasan ini peneleti

20 Sri Hastuti DKK. Urgensi Perluasan Permohonan Pembubaran Partai Politk di Indonesia., Jurnal Hukum Ius Quila Iustum Fakultas Hukum UII Volume 23 Isssue 4 2016, hal 555

${ }^{21}$ Ibid., hal 566 
mengambil langkah terkait dengan melalui proses pengadilan di dalam peradilan niaga yang akan memutuskan bahwa partai politik yang menyatakan baha partai politik tersebut dinyatakan pailit dan telah memiliki kekuatan hukum tetap sebagai partai politik yang pailit (inkracht) yang membuktikan bahwa partai politik dalam keadaan pailit.

B. Tahap Pengajuan Permohonan Kepada Mahkamah Konstitusi

Untuk membubarkan partai politik di Indonesia, pemohon untuk peroses pembubarannya adalah dilakukan oleh pemerintah dalam peraturan Mahkamah Konstitusi diatur terkait bagaimana proses permohonannya di Pasal 4 yaitu sebagai berikut:

1. Permohonan diajukan secara tertulis dalam bahasa Indonesia oleh pemohon atau kuasanya kepada Mahkamah;

2. Permohonan ditandatangani oleh pemohon atau kuasanya dalam 12 (dau belas rangkap);

3. Permohonan sekurang-kurangnya memuat:

a. Identitas lenhkap pemohon dan kuasanya jika dilengkapi kuasa khusu untuk itu;

b. Uraian yang jelas tentang ideology, asas tujuan, program dan kegiatan partai olitik yang dimohonkan pembubaran yang dianggap bertentangan dengan Undang-Undang Dasar Negara Republik Indonesia Tahun 1945;

c. Alat-alat bukti yang mendukung permohonan.

Artinya apabila pemerintah berkeinginan untuk mengusulkan pembubaran partai politik cukup dengan memnuhi prosedur administratif sebagaimana telah diatur dalam Peraturan Mahkamah Konstitusi Tersebut.

permohonan pembubaran partai politik yang telah diterima MK dicatat dalam Buku Registrasi Perkara Konstitusi. Selanjutnya MK menyampaikan permohonan yang sudah dicatat tersebut kepada partai politik yang bersangkutan dalam waktu paling lambat 7 (tujuh) hari kerja sejak pencatatandilakukan untuk kemudian diteruskan ketahap pemeriksaan pendahuluan dan persidangan.

\section{Tahap Persidangan di Mahkamah Konstitusi}

Merujuk kepada aturan hukum yang sedang berlaku saat ini, proses pemeriksaan persidangan pembubaran partai politik tidak diatur secara khusus, sehingga pemeriksaan persidangan selanjutnya mengikuti hukum acara Mahkamah Konstitusi yang meliputi pemeriksaan pendahuluan, pemeriksaan persidangan, dan putusan.

Akan tetapi dalam konteks ini karena merupakan konsep hukum atau Ius Constituendum maka penulis mendepskripsikan bahwa proses persidangan pembubaran partai politik di bagi menjadi lima tahap. pertama Dalam pemeriksaan pendahuluan permohonan pembubaran partai politik, dilaksanakan untuk memeriksa kelengkapan dan kejelasan alasan permohonan serta kedudukan hukum si pemohon. Adapun alasan pembubaran partai politik dalam hal inii adalah berkenaan dengan pailitnya partai politik maka dalam tahapan ini pemohon wajib membuktikan bahwa pemohon memang memiliki legal standing dalam mengajukan permohonan dan menjelaskan secara komprehensif bahwa alasan 
diajukannya permohonan pembubaran partai politk telah sesuai sebagaimana diatur didalam Undang-Undang yang dibuat nantinya.

Kedua persidangan dngan agenda lanjutan dalam rangka mendengarkan petitum termohon. Agenda ini dilaksanakan ketika permohonan yang diajukan oleh pemohon sudah lengkap dan dinyatakan lengkap oleh Mahkamah Konstitusi.

Ketiga, adalah agenda lanjutan untuk mendengarkan keterangan termohon setelah kemudian pemohon menyampaikan keterangan berkenaan dengan materi yang dimohonkan, dalam persidangan mendengarkan keterangan termohon,pihak termohon diberikan kesempatan dalam menyampaikan keteranganya berkenaan dengan permohonan yang diajukan oleh pemohon.

Keempat, persidangan pembuktian meliputi pembuktian dokumen serta keterangan-keterangan saksi ahli dan pihak-pihak terkait. Pembuktian dokumen dalam hal ini dapat dimaknai sebagai upaya untuk menilai apakah putusan pengadilan yang telah berkekuatan hukum tetap berkenaan dengan pailitnya partai tersebut dapat menjadi dasar dalam pengajuan permohonan pembubaran partai politik.

Tahap kelima adalah sidang pembacaan putusan. Setelah seluruh tahapan persidangan sebagaimana peneliti uraian di atas selesai dilaksanakan, tahapan selanjutnya adalah sidang pembacaan putusan. Peneliti membayangkan bahwa sidang putusan terhadap permohonan pembubaran partai politik dilaksanakan selambat-lambatnyan 90 hari kerja sejak permohonan diregistrasi. Dalam hal putusan pembubaran partai politk yang pailit dikabulkan maka Sesuai dengan ketentuan Pasal 10 ayat (1) PMK Nomor 12 Tahun 2008 tentang Prosedur Beracara dalam Pembubaran Partai Politik, dalam hal permohonan dikabulkan, amar putusan berbunyi:

a. mengabulkan permohonan pemohon;

b. menyatakan membubarkan dan membatalkan status badan hukum partai politik yang dimohonkan pembubaran;

c. memerintahkan kepada Pemerintah untuk: menghapuskan partai politik yang dibubarkan dari daftar pada Pemerintah paling lambat dalam jangka waktu 7 (tujuh) hari kerja sejak putusan Mahkamah diterima;

d. mengumumkan putusan Mahkamah dalam Berita Negara Republik Indonesia paling lambat 14 (empat belas) hari sejak putusan diterima.

Oleh karena itu, jika diputuskan permohonan pembubaran partai politik dikabulkan, pelaksanaannya dilakukan dengan membatalkan pendaftaran pada pemerintah yang berarti pembatalan status badan hukumnya.Putusan tersebut diumumkan oleh pemerintah dalam Berita Negara Republik Indonesia dalam jangka waktu 14 hari sejak putusan diterima Mengingat yang menangani pendaftaran partai politik adalah Kementerian Hukum dan HAM, maka pelaksanaan putusan Mahkamah Konstitusi adalah dalam bentuk pembatalan pendaftaran partai politik.

\section{PENUTUP}

Pendirian partai politik dimulai dengan pendaftaran partai politik kepada notaris dengan akta notaris tersebut partai politik dapat didaftarkan ke Departemen Hukum dan HAM. Setelah mekanisme pendaftaran dilaksakan maka disahkanlah pendirian partai politik sebagai badan hukum yang diumumkan oleh 
kementrian Hukum dan HAM. Hal ini tertuang dalam pasal 3 dan pasal 4 UndangUndang Nomor 2 Tahun 2011 tentang Partai politik. Partai politik didirikan sekurang-kurangnya oleh 30 orang warga Negara Indonesia yang telah berusia 21 Tahun. Syarat-syarat yang harus dipenuhi dalam pendirian partai politik yaitu ;

a. Mencantumkan pancasila sebagai dasar Negara Indonesia dalam anggaran dasar partai politik

b. Asas atau ciri, aspirasi dan program partai politik tidak bertentangan dengan pancasila

c. Keanggotaan partai politik bersifat terbuka untuk setiap warga Negara Indonesia yang telah mempunyai hak pilih;

d. Partai politik tidak boleh menggunakan nama atau lambang yang sama dengan lambang Negara Asing, Bendera Negara Indonesia Sang Merah Putih, Bendera kebangsaan Negara asing, gambar perorangan dan nama serta lambang partai lain yang telah ada.

2. Partai politk dapat juga dipailitkan seperti layaknya perseroan terbatas apabila partai politk memenuhi syarat-syarata kepailitannya dalam Undang-undang kepailitan belum mengatur secara khusus tentang pemailitan partai politik , karena tidak menutup kemungkinan partai politik bisa melakukan syarat-syarat kepailitan pada badan hukum. Walaupun telah kita ketahui bahwasanya partai politik dikaregorikan sebagai badan hukum publik yang di lihat dari sistem pembentukannya melalui perkumpulan orang yang memiliki pemikiran yang sama dan tujuan yang sama dalam organisasi dan Perseroan terbatas dikategorikan sebagai Badan hukum privat yang sistem pembentukannya melalui individu atau perseorangan. Namun tidak menutup kemungkinan bahwa partai politik dipailitkan adapun proses pemailitan partai politik adalah sama dengan proses pemailitan badan hukum yag lain seperti perseroan terbatas.

3. Akibat-akibat hukum dari putusan pailit terhadap keuangan partai politik adalah:

6. putusan pemailitan dapat dijalankan terlebih dahulu

putusan pengadilan dapat dijalankan terlebih dahulu, walaupun terhadap putusan pailit dan dilakukan suatu upaya hukum lebih lanjut. Apabila putusan pailit dibatalkan sebagai akibat dari adanya proses atau upaya hukum tersebut maka segaka perbuatan yang dilakukan oleh kurator dalam menjalankan tugasnyasebelum kurator menerima pemberitahuan tentang putusan pembatalan, mak tetap dan mengikat bagi parpol.

\section{Sitaan Umum}

Keuangan partai politik yang masuk didalam keuangan yang dinyatakan pailit merupakan sitaan umum, sita umum terhadap keuangan yang pailit tidak memerlukan suatau tindakan khusus untuk melakukan sitaan tersebut. Namum segala keuangan partai yang dinyatakan pailit berada dalam status dihentikan dari segala transaksi dan perbuatan hukum yang kain termasuk dana kampanye sampai dengan keuangan tersebut di urus atau dikelola oleh kurator.

8. Kehilanagan Wewenang Terhadap Keuangan Dan Kepengurusan Partai Partai politik yang pailit demi hukum kehilangan haknya untuk mengurus segala sesuatau yang berkaitan tentang keuangan partai politik dan juga 
kehilangan haknya dalam kepengurusan partai politik namun anggota dan mantan pengurus partai politik tidak akan kehilangan hak-hak sebagai warga negara seperti hak politik dan hak privat lainya yang melekat kepada setiap waga negara Republik Indonesia.

9. Penetapan Putusan Pengadilan Sebelumnya

Pernyataan pailit juga berakibat segala penetapan pelaksanaan pengadilan terhadap setiap bagian dari keuangan partai yang di mulai sebelum terjadinya kepailitan, harus diberhentikan seketika dan sejak itu tidak ada suatu putusan yang dapat dilaksanakan diluar wewenang pengadilan.

10. Hubungan Pengurus Dan Anggota Partai Politik Yang Pailit

Anggota dan pengurus partai politik dapatberhenti dari keanggotaan dan kepengurusan kepartaian dan sebaliknya kurator dapat memberhentikan anggota parpol dalam jangka waktu menurut persetujuan dan dalam ketentuan peraturan perundang-undangan yang akan dibuat nantinya.

akibat hukum pembubaran partai politik yang dinyatakan pailit adalah:

a. Pelarangan hak hidup partai politik dan penggunaan simbol-simbol partai tersebut di seluruh Indonesia;

b. Pemberhentian seluruh anggota DPR dan DPRD yang berasal dari partai politik yang dibubarkan;

c. Pelarangan terhadap mantan pengurus partai politik yang dibubarkan untuk melakukan kegiatan politik; dan

d. Pengambilalihan oleh negara atas kekayaan partai politik yang dibubarkan

\section{DAFTAR PUSTAKA}

C.F Strong.2011 Konstitusi - Konstitusi Modern. Bandung. Nusa Media.

Erlanda Juliansyah Putra, Gagasan Pembubaran Partai Politik Korup Di Indonesia, PT. RajaGrafindo Persada, Depok 2017;

Hans Kalsen, Teori Hukum Murni , Nusa Media , Bandung 2008;

Jimly Asshiddiqie, Pengantar Ilmu Hukum Tata Negara Jilid II. Sekretariat Jendral dan kepaniteraan Mahkamah Konstitusi RI, Jakarta 2006;

Jimly Asshiddiqie, "Pokok - Pokok Hukum Tata Negara Indonesia Pasca Reformasi”. PT Bhuana Ilmu Populer Kelompok Gramedia, Jakarta 2007;

Jimly asshiddiqie, Menuju Negara Hukum Yang Demokratis. PT. Bhuana Ilmu Populer Jakarta.2009;

Jimly Asshiddiqie, Pengantar Ilmu Hukum Tata Negara Jilid I. Sekretariat Jendral dan kepaniteraan Mahkamah Konstitusi RI, Jakarta 2006;

Jimly Asshiddiqie, Perkembangan \&konsolidasi Lembaga negara, Jakarta Sinar Grafika, 2006;

Jimly Asshiddiqie. Islam dan kedaulatan rakyat. Gema Insani, 1995;

Jimly Asshiddiqie Konstitusi dan konstitusialisme Indonesia. Edisi Kedua Cetakan Pertama, Sinar Grafika, Jakarta Timur,2011;

Jimly Asshiddiqie, perkembangan \& konsolidasi lembaga Negara pasca reformasi, sinar grafika, Jakarta 2010. 
Jhonny Ibrahim, Teori Dan Metodologi Penelitian Hukum Normatif, Bayumedia, Malang, 2006;

Moh. Ali Safa'at : Pembubaran Partai Politik, Rajagrafindo Persada, Depok; 2017

Mohtar Mas'oed dan colin MacAndrews, PERBANDINGAN SISTEM POLITIK, Gadjah Mada University Press. Jogjakarta 2006;

Miriam Budiardjo , DASAR- DASAR ILMU POLITIK, Gramedia Pustaka Utama Jakarta 2008;

Maria SW.Sumardjono, Metodologi Penelitian Ilmu Hukum, Yogyakarta, Universitas Gajah Mada, 2014;

Mochtar Kusumaatmadja dan EttyR. Agoes 2002. Pengantar hukum Internasional. Bandung. Alumni.

Muhadam labolo dkk, Partai Politik dan Sistem Pemilihan Umum Di Indonesia teori,konsep dan isu strategis, PT. RajaGrafindo Persada,. Jakarta. 2015;

Mustafa Lutfi \& M.Iwan Satriawan, Risalah Hukum Partai Politik Di Indonesia,. UB Press, Malang 2016;

Peter Mahmud Marzuky, Penelitian Hukum. Cetakan Keenam, Jakarta; Kencana ,2010;

Ramlan Surbakti, Memahami Ilmu Politik, Jakarta Gramedia Widiasarana Indonesia, 2007.

Sri Hastuti DKK. Urgensi Perluasan Permohonan Pembubaran Partai Politk di Indonesia., Jurnal Hukum Ius Quila Iustum Fakultas Hukum UII Volume 23 Isssue 4 2016

Undang-Undang Dasar Negara Republik Indonesia 1945

Undang-Undang Nomor 24 Tahun 2003 Tentang Mahkamah Konstitusi. Tambahan Lembaran Negara Republik Indonesia Nomor 4316

Undang-Undang Nomor 8 Tahun 2011 Tentang Perubahan Undang-Undang Nomor 24 Tahun 2003 Tentang Mahkamah Konstitusi, Tambahan Lembaran Negara Republik Indonesia Nomor 5226

Nomor 2 Tahun 1999 tentang Partai Politik Tambahan Lembaran Negara Nomor 3809

Undang-Undang Nomor 7 Tahun 2017 Tentang Pemilihan Umum, Tambahan Lembaran Negara Nomor 6109

Undang-Undang Nomor 11 Tahun 2006 tentang Pemerintahan Aceh,Tambahan Lembaran Negara Nomor 4633

Undang-Undang Nomor 21 Tahun 2001 Tentang Otonomi Khusus Bagi Provinsi Papua Tambahan Lembaran Negara Nomor 4842

Undang-Undang Nomor 2 Tahun 2008 Tentang Partai Politik Tambahan Lembaran Negara Nomor 4801

undang-undang nomor 37 Tahun 2004 Tentang kepailitan,Tambahan Lembaran Negara Nomor 4443

Undang-Undang Nomor 2 Tahun 2011 Tentang perubahan atas Undang-Undang Nomor 2 Tahun 2008. Tambahan Lembaran Negara Nomor 5189

Undang-Undang Nomor 31 Tahun 2002 Tentang Partai Politik, Tambahan Lembaran Negara Nomor 4251

Peraturan MK Nomor 12 Tahun 2008 Tentang Prosedur beracara dalam pembubaran partai politik 